\title{
POJĘCIE SŁUSZNOŚCI A OKREŚLANIE WYSOKOŚCI OPŁAT WYNIKAJĄCYCH Z USTAWY O GOSPODARCE NIERUCHOMOŚCIAMI
}

\section{Wprowadzenie}

Celem artykułu jest przedstawienie jak ustawa o gospodarce nieruchomościami (UoGN) wskazuje w jaki sposób określić wysokość opłat wymienionych w ustawie oraz czy przy ustalaniu tych opłat będzie miała zastosowanie zasada słuszności.

Słuszność jest jedną z klauzul generalnych, która ma zastosowanie w prawie polskim. Korzenie słuszności sięgają czasów starożytnych, pojęcie to ewoluowało aż do czasów współczesnych. Jak stwierdziła Katarzyna Sójka-Zielińska, kodyfikacja prawa to przejście od idei zupełności prawa do zwiększania otwarcia norm. ${ }^{1}$ Klauzula generalna to wyrażenie niedookreślone, którego celem jest wprowadzenie pewnej dowolności w wykładni prawa. Klauzula generalna pozwala na szersze zastosowanie przepisów prawa. ${ }^{2}$ Klauzule generalne mogą być traktowane jako ,pomost”, którego celem jest łączenie norm prawnych z normami pozaprawnymi. ${ }^{3}$

Zasada słuszności ma zastosowanie w różnych gałęziach prawa. Słuszność jest pojęciem niedookreślonym. Można spróbować ją zdefiniować jako coś, co jest właściwe, prawdziwe, ${ }^{4}$ może to też być coś zgodnego z prawdą. ${ }^{5}$ Słuszność więc powinna być możliwie najbliższa prawdzie, jednakże nie jest to pojęcie równoznaczne z pojęciem prawdy. Zasada słuszności jest zasadą podrzędną względem zasady sprawiedliwości, która jest zasadą fundamentalną prawa pozytywnego. ${ }^{6}$ Słuszność pro-

\footnotetext{
K. Sójka-Zielińska, Wielkie kodyfikacje XIX w., Warszawa 1973.

A. Korybski, L. Leszczyński, A. Pieniążek, Wstęp do prawoznawstwa, Lublin 2005, s. 138.

M. Safjan, Klauzule generalne w prawie cywilnym (przyczynek do dyskusji), „Państwo i Prawo” 1999, z. 11, s. 51. http://www.wsjp.pl/index.php?id_hasla=36333\&id_znaczenia=4617441\&l=22\&ind=0 (dostęp dnia: 1 listopada 2014 r.)

5 http://sjp.pwn.pl/szukaj/s\%C5\%82uszno\%C5\%9B\%C4\%87 (dostęp dnia: 1 listopada 2014 r.)

6 V. Coman, L. Boboc, O. Steriopol, Equity, fundamental principle of law, „Contemporary readingis in law and social justice" 2012, vol. 4(2), s. 468.
} 
wadzi do dopasowania konkretnych norm prawnych do indywidualnych sytuacji, dzięki czemu prawo przez swoją ogólność nie jest „tyranem”. ${ }^{7}$ Można wyróżnić słuszność indywidualną lub generalną. ${ }^{8}$ Słuszność indywidualna występuję wtedy, gdy wydawane jest rozstrzygnięcie w konkretnej sprawie, słuszność generalna zakłada zgodność rozstrzygnięcia z normą niemającą charakteru prawnego. ${ }^{9}$ Do słuszności w ujęciu generalnym odwołanie następuje, gdy w prawie pojawia się luka. ${ }^{10}$

\section{Zasada słuszności przy określaniu wysokości opłat wynikających z ustawy o gospodarce nieruchomościami}

Nieruchomość może być przedmiotem obrotu pomiędzy podmiotami prywatnymi i podmiotami publicznymi. Artykuł 13 ustawy o gospodarce nieruchomościami ${ }^{11}$ określa, że nieruchomości mogą być przedmiotem różnych czynności prawnych, w szczególności: sprzedaży, zamiany, zrzeczenia się, oddania w użytkowanie wieczyste, najem, dzierżawę, użyczenie nieruchomości można oddać w trwały zarząd, można je obciążyć ograniczonymi prawami rzeczowymi, jak również mogą być wnoszone, jako wkład niepieniężny do spółek, przekazane jako wyposażenie tworzonych przedsiębiorstw państwowych oraz jako majątek tworzonych fundacji. Pod pojęciem nieruchomości znajdują się trzy rodzaje nieruchomości: nieruchomość gruntowa, budynkowa i lokalowa. Definicje rodzajów nieruchomości zawiera art. 46 $\S 1$ kodeksu cywilnego. ${ }^{12}$ Występują rozbieżności, który rodzaj nieruchomości może podlegać konkretnej procedurze, np. w użytkowanie wieczyste mogą być oddane wyłącznie nieruchomości gruntowe. Przepisy dopuszczają również wywłaszczenie nieruchomości nie określając, o jaki rodzaj nieruchomości chodzi, zawężając jedynie do przeznaczenia tej nieruchomości w planach miejscowych na cele publiczne bądź czy została wydana decyzja o ustaleniu lokalizacji inwestycji celu publicznego.

Ustawa o gospodarce nieruchomościami określa, jak należy określać wysokość różnych opłat związanych z obrotem nieruchomościami. Określone jest też, że niektóre podmioty nie muszą płacić pełnej wartości nieruchomości. Artykuł 14 ustawy stanowi, że nieruchomości mogą być sprzedane dla jednostek samorządu terytorialnego za cenę niższą niż ich wartość rynkowa bądź mogą być oddane w użytkowanie wieczyste bez pobierania opłaty pierwszej. Wartość rynkową nieruchomości stanowi najbardziej prawdopodobna cena danej nieruchomości, którą można uzyskać na rynku, tak stanowi art. 151 ust. 1 ustawy o gospodarce nieruchomościami. Usta-

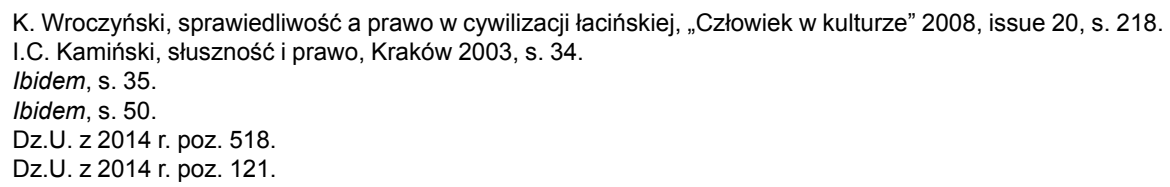


Pojęcie słuszności a określanie wysokości opłat wynikających z ustawy...

lenie takiej ceny następuje $\mathrm{z}$ uwzględnieniem cen transakcyjnych. Przy określaniu wartości rynkowej należy uwzględnić następujące założenia:

- Strony umowy były od siebie niezależne, nie działały w sytuacji przymusowej oraz miały stanowczy zamiar zawarcia umowy;

- Upłynął czas niezbędny do wyeksponowania nieruchomości na rynku i do wynegocjowania warunków umowy.

Oprócz wartości rynkowej występują też inne wartości, art. 150 wymienia wartość rynkową, odtworzeniową, katastralną, jak również możliwość określenia innych rodzajów wartości określonych w innych przepisach. Podmiotem, który określa wartość nieruchomości, jest rzeczoznawca majątkowy; uprawnienie do określania wartości nadaje mu art. 7 ustawy o gospodarce nieruchomościami (UoGN). Ustawa określa, jakie występują podejścia do wyceny nieruchomości. Metody wyceny są opisane w rozporządzeniu Rady Ministrów w sprawie wyceny nieruchomości i sporządzenia operatu szacunkowego ${ }^{13}$ oraz $\mathrm{w}$ standardach zawodowych i notach interpretacyjnych, które powinny być wskazówkami, jak dokonywać procedury szacowania.

Opłaty związane z obrotem, obciążeniem czy innymi zdarzeniami prawnymi na nieruchomości wynikają z różnych przepisów prawa. Ustawa o gospodarce nieruchomościami jest aktem przykładowym do dalszych rozważań. Została ona przyjęta do analizy ze względu na bardzo szeroki zakres tematyczny i uwzględnienie wielu aspektów związanych z nieruchomościami. W ustawie określony został obrót nieruchomościami pomiędzy podmiotami publicznymi. Przykładem może być art. 14, norma zawarta $\mathrm{w}$ tym artykule określa, że sprzedaż nieruchomości należących do Skarbu Państwa może odbyć się za cenę niższą niż jej wartość rynkowa, jeśli jest nabywana przez jednostki samorządu terytorialnego. Wynika z tego, że nieruchomość może być przedmiotem sprzedaży i jednostka samorządu terytorialnego, która nabywa może zapłacić za nieruchomość mniej niż zapłaciłaby osoba fizyczna. Również oddanie nieruchomości należącej do Skarbu Państwa w użytkowanie wieczystej jednostce samorządu terytorialnego może odbyć się bez uiszczenia opłaty pierwszej. Opłata pierwsza zgodnie z art. 72 ust. 2 UoGN wynosi od $15 \%$ do $25 \%$ ceny nieruchomości gruntowej i powinna być uiszczona do podpisania umowy o oddanie nieruchomości gruntowej w użytkowanie wieczyste. Artykuł 73 ust. 3 UoGN przewiduje udzielenie bonifikaty od opłaty pierwszej i opłat rocznych, nie przewiduje jednak zwolnienia z opłaty pierwszej. Bonifikata jest również przewidziana, jeśli nieruchomość została wpisana do rejestru zabytków, przysługuje wtedy $50 \%$ bonifikaty. Zwolnienie z opłaty pierwszej występuje jedynie w odniesieniu do jednostek samorządu terytorialnego i to tylko, kiedy nabywają użytkowanie wieczyste od Skarbu Państwa. 
W wypadku zamiany nieruchomości między Skarbem Państwa a jednostkami samorządu terytorialnego nie ma obowiązku dopłat (art. 14 ust. 3), gdy występuje różna wartość tych nieruchomości, kiedy jednym z podmiotów jest osoba fizyczna lub prawna występuje obowiązek zastosowania dopłaty (art. 15 ust. 1). Dopłata równa jest różnicy w wartości nieruchomości. Konieczność zastosowania dopłat występuje więc, jeśli jednym z podmiotów jest osoba fizyczna lub prawna. Dopłata może być wypłacona na rzecz Skarbu Państwa czy jednostki samorządu terytorialnego, jak również osoby fizycznej czy prawnej. Dopłata jest ustalana na podstawie wartości nieruchomości, którą należy określić na podstawie odrębnych przepisów.

Zbycie prawa własności, użytkowania wieczystego następuje w drodze przetargowej lub bezprzetargowej. Cena nabycia prawa w drodze przetargu zależna jest od wartości nieruchomości. Cena wywoławcza w pierwszym przetargu nie może być niższa niż wartość nieruchomości (art. 67 ust. 2 pkt 1 UoGN). Najniższa możliwa do uzyskania cena nabycia to cena wywoławcza i jedno postąpienie ( $\$ 14$ ust. 3 rozporządzenia stanowi, że postąpienie wynosi nie mniej niż $1 \%$ ceny wywoławczej). ${ }^{14}$ Nabycie prawa w pierwszym przetargu będzie wyższe od wartości rynkowej tego prawa, przepisy prawa regulują zbycie nieruchomości należących do Skarbu Państwa lub jednostek samorządu terytorialnego w związku z tym, jeśli osoba fizyczna czy prawna chce nabyć w przetargu prawo, to cena nabycia będzie wyższa od wartości nieruchomości. W wypadku, gdy prawo nie zostanie nabyte w przetargu pierwszym, istnieje możliwość przeprowadzenia przetargu drugiego.

Gdyby zastosować zasadę słuszności należałoby określać ceny nabycia prawa na poziome jak najbardziej prawdziwym. Ciekawe podejście do słuszności zostało przedstawione w artykule Marka Bożykowskiego. Wskazuje on, że słuszny podział dóbr jest wtedy, gdy każdy z uczestników otrzymuje taką część całości według swojej oceny jak inni uczestnicy wedle własnych ocen. ${ }^{15} \mathrm{~W}$ takim wypadku słuszne byłoby określenie wysokości ceny nabycia, którą każdy z podmiotów uważałby za właściwą dla niego. Z wyżej wymienionych norm prawnych widać dysproporcje w określaniu cen nabycia prawa. Gdy podmiotem jest jednostka samorządu terytorialnego, to może nabyć prawo za cenę niższą niż wartość nieruchomości bądź może być zwolnione z opłat. Jeśli podmiotem jest osoba fizyczna bądź prawna, zwolnienia nie występują, a cena nabycia może być wyższa do wartości rynkowej.

Innym typem opłaty, która wynika z ustawy o gospodarce nieruchomościami jest opłata adiacencka. Jest to opłata, która została zdefiniowana w art. 4 pkt 11 UoGN, jako opłata ustalona w związku ze wzrostem wartości nieruchomości spowodowanym budową urządzeń infrastruktury technicznej z udziałem środków Skarbu Państwa, jednostek samorządu terytorialnego, środków pochodzących z budżetu

\footnotetext{
14 Rozporządzenie Rady Ministrów w sprawie sposobu i trybu przeprowadzania przetargów oraz rokowań na zbycie nieruchomości z dnia 14 września 2004 r. Dz.U. z 2004 r. Nr 207, poz. 2108.

15 M. Bożykowski, Procedury podziału zbioru dóbr niepodzielnych z rekompensatami pieniężnymi, „Decyzje” 2011, nr 15, s. 8.
} 
Pojęcie słuszności a określanie wysokości opłat wynikających z ustawy...

Unii Europejskiej lub ze źródeł zagranicznych niepodlegających zwrotowi, albo opłatę ustaloną w związku ze scaleniem i podziałem nieruchomości, a także podziałem nieruchomości. Opłata ta występuje w trzech sytuacjach, a podmiotami, które ją płaca są właściciele i użytkownicy wieczyści nieruchomości. Opłatę liczy się według wzoru:

$$
\mathrm{OA}=\mathrm{b}^{*}\left(\mathrm{~W}^{\mathrm{II}}-\mathrm{W}^{\mathrm{I}}\right) \text {, gdzie: }
$$

b - stawka procentowa ustalana przez radę gminy,

$\mathrm{W}^{\mathrm{II}}$ - wartość nieruchomości po wybudowaniu urządzeń infrastruktury technicznej, po dokonaniu scalenia i podziału nieruchomości i w związku z podziałem nieruchomości,

$\mathrm{W}^{\mathrm{I}}$ - wartość nieruchomości przed wybudowaniem urządzeń infrastruktury technicznej, przed procedurą scalenia i podziału oraz przed podziałem nieruchomości.

Wysokość stawki procentowej opłaty adiacenckiej jest uzależniona od konkretnej procedury oraz od uchwały rady gminy, która taką stawkę określi. Przy podziale nieruchomości maksymalna stawka procentowa opłaty adiacenckiej na podstawie art. 98a ust. 1 UoGN może wynosić $30 \%$. Przy procedurze scalenia i podziału stawka może maksymalnie wynosić 50\% (art. 107 ust. 1 UoGn), przy budowie urządzeń infrastruktury technicznej również stawka maksymalna wynosić może 50\% (art. 146 ust. 2 UoGN).

Ustalenie opłaty adiacenckiej jest uzależnione od wartości nieruchomości oraz od tego, czy organ będzie chciał taką opłatę na podmiot nałożyć. Ustalenie opłaty nie jest obowiązkowe.

Ustawa o gospodarce nieruchomościami określa, że nieruchomość może podlegać wywłaszczeniu. $Z$ art. 112 ust. 2 wynika, że wywłaszczenie to pozbawienie, ograniczenie prawa do nieruchomości. Z analizy przepisów UoGn wynika, że przesłanki wywłaszczenia są następujące:

a) Wywłaszczyć można jedynie nieruchomość;

b) Nieruchomości przeznaczone pod wywłaszczenie muszą być przeznaczone w planach miejscowych na cele publiczne (obszary przeznaczone do realizacji celu publicznego albo została wydana decyzja o ustaleniu lokalizacji inwestycji celu publicznego);

c) Wywłaszczyć można na rzecz Skarbu Państwa lub jednostek samorządu terytorialnego;

d) Wywłaszczenie może być dokonane tylko na cel publiczny;

e) Wywłaszczana nieruchomość jest niezbędna do realizacji celu publicznego;

f) Nieruchomości nie można pozyskać w inny sposób niż przez wywłaszczenie;

g) Wywłaszczenie dokonuje się za słusznym odszkodowaniem. 
Przesłanka słusznego odszkodowani wynika z art. 21 Konstytucji Rzeczpospolitej Polskiej. ${ }^{16} \mathrm{~W}$ artykule tym znajduje się zapis, że odszkodowanie za wywłaszczenie powinno być odszkodowaniem słusznym. Odszkodowanie za wywłaszczenie jest jedyną „opłatą”, w stosunku do której zostało określone, że musi być ona słuszna.

Odszkodowanie za wywłaszczenie jest związane $\mathrm{z}$ utratą, ograniczeniem prawa do nieruchomości. Inne opłaty, które wynikają z ustawy o gospodarce nieruchomościami występują, kiedy podmiot nabywa prawo czy wartość jego nieruchomości wzrasta. Ustawa nie przewiduje innej sytuacji, kiedy podmiot wbrew swojej woli zostaje pozbawiony prawa do nieruchomości. Wywłaszczenie jest poprzedzone rokowaniami, w których strony dążą do zawarcia umowy sprzedaży przedmiotowej nieruchomości. Ustawa nie określa, jaka powinna być cena nabycia nieruchomości w rokowaniach przed wywłaszczeniem. Korzystając z zasady swobody umów należy przyjąć, że cena w rokowaniach może zostać ustalona dowolnie przez podmioty. Podmiot, który chce nabyć prawo do nieruchomości, może negocjować wysokość ceny, jaką chce zapłacić za nieruchomość. Jeśli nie dojdzie do nabycia nieruchomości w drodze rokowań, można przeprowadzić wywłaszczenie. Za wywłaszczoną nieruchomość przysługuje odszkodowanie. Ustawa o gospodarce nieruchomościami w art. 134 określa, że podstawą ustalenia wysokości odszkodowania jest wartość rynkowa, jeśli wartość rynkowa nie może zostać określona, odszkodowanie określa się na podstawie wartości odtworzeniowej (art. 135). Ustawa w art. 128 dokładniej określa, że jeśli na nieruchomości występują inne prawa, np. ograniczone prawa rzeczowe, to odszkodowanie pomniejsza się o wartość tych praw.

W ustawie o gospodarce nieruchomościami nie ma odwołania do zasady słuszności wyartykułowanej w art. 21 Konstytucji, według którego odszkodowanie musi być słuszne. Żeby stwierdzić, co to znaczy słuszne odszkodowanie należy przytoczyć Wyrok Trybunału Konstytucyjnego, który odnosi się do zagadnienia słusznego odszkodowania. ${ }^{17} \mathrm{~W}$ wyroku tym Trybunał Konstytucyjny wskazał, że nie mamy definicji słusznego odszkodowania. Pojęcie słusznego odszkodowania związane jest z wywłaszczeniem nieruchomości. Trybunał Konstytucyjny zauważył, że ustawodawca nie posługuje się określeniem pełne odszkodowanie. Termin słuszne odszkodowanie jest pojęciem bardziej elastycznym. Może z tego wynikać, że odszkodowanie może być słuszne nawet nie będąc w pełni ekwiwalentne. Naliczając odszkodowanie należy wyważyć interes prywatny, jak również interes publiczny. Wypłacenie pełnego odszkodowania może naruszać zasadę słuszności. A z kolei wypłacenie nie w pełni ekwiwalentnego odszkodowania może być uznane za słuszne odszkodowanie.

Określając wysokość odszkodowania należy uwzględnić stan, przeznaczenie i wartość wywłaszczonej nieruchomości. Należy określić to na dzień wydania decy- 
Pojęcie słuszności a określanie wysokości opłat wynikających z ustawy...

zji o wywłaszczeniu. Gdyby decyzja o odszkodowaniu była wydana w innym terminie niż decyzja o wywłaszczeniu, to należy określić wartość odszkodowania według stanu i przeznaczenia nieruchomości w dniu pozbawienia lub ograniczenia prawa.

Jako odszkodowanie może być również przyznana nieruchomość zamienna. Otrzymanie takiej nieruchomości może nastąpić jedynie za zgodą podmiotu, którego pozbawiamy prawa. Nieruchomość zamienna przyznawana jest z zasobu nieruchomości Skarbu Państwa bądź jednostek samorządu terytorialnego w zależności, na czyją rzecz wywłaszczenie następuje. W ustawie o gospodarce nieruchomościami nie występuje definicja nieruchomości podobnej. W wypadku, kiedy przyznana nieruchomość zamienna ma inną wartość niż nieruchomość wywłaszczana, należy zastosować dopłaty pieniężne, które mają wyrównać rożnicę między wartościami nieruchomości.

\section{Zakończenie}

Przepisy ustawy o gospodarce nieruchomościami nie uwzględniają przy wyliczeniu wysokości opłat zasady słuszności. Opłaty są wyliczane z uwzględnieniem wartości nieruchomości. Zasada słuszności w ujęciu indywidualnym nie ma zastosowania. Podmiot nalicza czy to opłaty przy użytkowaniu wieczystym, czy wysokość opłat adiacenckich kierując się tylko tym, ile dana nieruchomość jest warta na rynku. Wprowadzenie zasady słuszności, jako jednej z zasad do ustawy o gospodarce nieruchomościami doprowadzi do tego, że będzie ona przywiązywała większą wagę do indywidualnych możliwość osób, które mają uiszczać opłatę. Podmioty, które biorą udział w obrocie nieruchomościami zgodnie z ustawą są nierówno traktowane. Skarb Państwa i jednostki samorządu terytorialnego są uprzywilejowane i obrót nieruchomościami w stosunku do nich może odbywać się za ceny niższe niż wartość nieruchomości. Osoby fizyczne i prawne, jeśli chcą nabyć prawa są obowiązane do zapłaty pełnych wartości, a czasem od razu wiedzą, że zapłacą więcej niż wartość nieruchomości - przy nabyciu prawa w drodze przetargu.

Opłaty nakładane przez organ, nakładane są w formie decyzji administracyjnej. Daje to możliwość podmiotowi obrony przed za wysoką czy niesłusznie nałożoną opłatą. Wprowadzenie możliwości określania wysokości opłat wynikających z ustawy o gospodarce nieruchomościami może prowadzić do zachwiania poczucia sprawiedliwości i równości społecznej. Dlatego też stosowanie zasady słuszności przy określaniu opłat musi być ostrożne. Określenie przez ustawodawcę, że przy określaniu odszkodowania za wywłaszczenie należy określić odszkodowanie słuszne jest ważne, gdyż daje możliwość podwyższenia odszkodowania nawet ponad wartość nieruchomości. 


\section{PRINCIPLE OF EQUITY AND CALCULATING FEES BASED ON ACT OF REAL ESTATE MANAGEMENT}

The purpose of this article is to illustrate that the law in real estate management, which is one of the most important instruments in the calculation of property management fees, does not take into account the principle of equitability. In determining the amount of fees, the operator is obliged to follow the market value which the law sets. Only the determination of compensation for the expropriation of real estate incorporated in the Polish Constitution, specifies that compensation must be eqiutable. Determination of the fees based solely on the value of the property should disable subjectivity in determining the fee. However, such a finding could lead to charges that the person required to pay the fee could feel that his particular charge is not correct in the individual case.

Keywords: principle of equity, real estate management, compensation 